\title{
EMERGENCY METHODS FOR RHESUS GROUP DETERMINATION
}

\author{
BY \\ J. C. F. POOLE AND G. C. J. WILliaMS \\ From the Division of Laboratories, Radcliffe Infirmary, Oxford
}

(RECEIVED FOR PUBLICATION JULY 17, 1950)

The most reliable method for Rhesus group determination is probably the standard tube method (Landsteiner and Wiener, 1941; Boorman, Dodd, and Mollison, 1942; Taylor, 1943). This technique has only one serious disadvantage: it may take as long as two hours to perform, although occasional high-avidity anti-D sera will give clearcut results in 30 minutes or even less. For emergency Rhesus typing a considerably quicker procedure is desirable. Rapid methods which have been described include the Chown capillary tube test (Chown, 1944 ; Chown and Lewis, 1946) and the Diamond slide test (Diamond and Abelson, 1945). Mollison, Mourant, and Race have recommended centrifuging after ten minutes' incubation as a means of accelerating agglutination in the tube method.

In pre-transfusion Rhesus grouping in this laboratory, it has been the practice for some time to use the Chown method. The results were checked by the tube method carried out by a different observer working in a separate room. Where both tests were in agreement, it was assumed that the correct result had been found: whenever discrepancies occurred, investigations were repeated until no reasonable doubt remained. After several hundred parallel observations had been made in this way, it became clear that the Chown test, at any rate with the technique in use, was not altogether satisfactory: both false positive and false negative results were occasionally encountered. We therefore decided to carry out a number of experiments to try to discover the reasons for incorrect results in the Chown test, and to determine as far as possible the optimum conditions for the test. At the same time a trial of the tube centrifuging method was made in parallel with the other two techniques.

We aim in this paper to compare the reliability of three methods for Rhesus group determination as used in a routine laboratory ; to draw attention to some sources of error in the Chown test ; and to describe the conditions in which satisfactory results can be obtained with the tube centrifuging method.

\section{Methods}

The Chown Test.-A thick suspension of cells in their own serum is obtained by shaking up the remains of a clotted specimen of blood after most of the serum has been removed. This is allowed to fall through a column of anti-D serum in a capillary tube set up in a small lump of plasticine and inclined at an angle of $45^{\circ}$. Approximately equal volumes of cell suspension and anti-D serum are used. The test is carried out at room temperature and read after 15 minutes. This technique is substantially the same as that advocated by Mollison $e t$ al. (1948). Standard vaccine capillary tubes have been used in most of the experiments, as 
these are of convenient size and approximately uniform bore $(0.7$ to $0.9 \mathrm{~mm}$.). In some of the experiments these conditions have been varied.

The Tube Method.-One drop of a $2 \%$ cell suspension in citrate saline $(0.5 \%$ sodium citrate, $0.85 \%$ sodium chloride) is mixed with one drop of anti-D serum in a $2 \frac{1}{2} \times \frac{3}{8}$-in. testtube and placed in an incubator at $37^{\circ} \mathrm{C}$. The results are read after two hours.

The Tube Centrifuging Method.-The cell suspension and anti-D serum are mixed in a small test-tube as before. The tube is placed in a $37^{\circ} \mathrm{C}$. water bath for 10 minutes and is then centrifuged for five minutes at 2,000 to 2,500 r.p.m. The test is read by rotating the tube gently between the thumb and forefinger : a positive result is indicated by a mass of agglutinated cells which becomes detached from the base of the tube and is surrounded by clear fluid ; if the result is negative, the cells, when rotated, will spiral upwards in supernatant fluid. It is sometimes necessary to shake the tube gently after rotation in order to see the result clearly, but vigorous shaking should be avoided, as it tends to break up the agglutination.

\section{Results}

In 917 consecutive routine determinations of the Rhesus group by the Chown method in parallel with the standard tube method, 20 discrepancies occurred. In each case the Chown test was found to be at fault : there were nine false positive and 11 false negative results. In the last 360 of these observations, the tube centrifuging method was used in addition to the other two tests. No discrepancies between the standard tube method and the tube centrifuging method arose, but the Chown test gave three false positive and four false negative results. In a further 180 observations the standard tube method and the tube centrifuging method were in complete agreement. Thus 540 consecutive observations were performed by the tube centrifuging method without error.

\section{Factors Affecting the Reliability of the Chown Test}

Experiments designed to investigate the various factors influencing the success or failure of the Chown test were carried out as described below. Several different anti-D sera were used in the different experiments, but in any one experiment the same serum was always used.

Temperature.-Previous workers have recommended incubation of the capillary tubes at $37^{\circ} \mathrm{C}$., and this seems logical since agglutination with Rhesus antibodies is known to take place most rapidly at this temperature. However, it is more convenient to perform the test at room temperature, and we find that agglutination at room temperature is not in fact much slower. Table I shows the time taken for the test to become positive at $19^{\circ} \mathrm{C}$. and at $37^{\circ} \mathrm{C}$. for ten blood samples.

A disadvantage of incubation lies in the fact that at $37^{\circ} \mathrm{C}$. the agglutinated clumps of cells in a positive reaction fall more rapidly to the bottom of the capillary tube and become packed together. Finally, the appearance differs very little from that of a

TABLE I

Time Required for Positive Results in Ten Samples at Two Temperatures

\begin{tabular}{c|c|c|c}
\hline \multirow{2}{*}{ Temperature } & $\begin{array}{c}\text { Average Time to } \\
\text { Reach Positive Result }\end{array}$ & \multicolumn{2}{c}{ Shortest and Longest Times } \\
\hline $19^{\circ} \mathrm{C}$. & $9^{\prime} 0^{\prime \prime}$ & $7^{\prime} 20^{\prime \prime}$ & $13^{\prime} 30^{\prime \prime}$ \\
$37^{\circ} \mathrm{C}$. & $6^{\prime} 50^{\prime \prime}$ & $4^{\prime} 40^{\prime \prime}$ & $8^{\prime} 50^{\prime \prime}$ \\
\hline
\end{tabular}


negative test left for a similar period. At room temperature there is a longer period during which positive and negative results are easily distinguishable.

Diameter of Capillary Tubes.-Fifty observations were made using capillary tubes of internal diameter varying from 0.3 to $1.4 \mathrm{~mm}$. The times taken for a positive result to appear are shown in Fig. 1. There is evidently no correlation between the two factors over the range of sizes used in this experiment. There is, however, a considerable difference in the clarity of the results, those in the largest and smallest sizes in this range being much less distinct than those in the intermediate values. An internal diameter of 0.6 to $0.9 \mathrm{~mm}$. seems to give the best results.

Effect of Rouleau Formation in Producing False Positives.-In a number of instances in which false positive results were obtained, it was noticed that the patients were suffering from conditions likely to give rise to a raised erythrocyte sedimentation rate (E.S.R.), and it therefore seemed probable that the apparent agglutination obtained in these cases might in fact be due to rouleau formation. It was soon found that a cell suspension made in the way described and drawn into a capillary tube supported at an angle of $45^{\circ}$ would rapidly give the appearance of a positive reaction when no anti-D serum had in fact been added. The macroscopic appearance was indistinguishable from that of a true positive result, and a check by microscopic examination was not possible as the red cell clumps dispersed in either case on transferring them to a slide.

In order to discover the conditions under which false positive reactions arose, we selected a number of blood specimens from patients known to have a high E.S.R. Table II shows the reactions obtained with and without anti-D serum in seven

TABLE II

analysis of Reactions with and without anti-D Serum in Seven Rh-positive Patients

\begin{tabular}{|c|c|c|c|c|c|c|c|}
\hline $\begin{array}{l}\text { E.S.R. } \\
\text { (mm. in } \\
1 \text { hour } \\
\text { Wester- }\end{array}$ & & \multicolumn{6}{|c|}{$\begin{array}{l}\text { Dilution of Packed Cells } \\
\text { in their Own Serum }\end{array}$} \\
\hline & & $40 \%$ & $30 \%$ & $20 \%$ & $10 \%$ & $5 \%$ & $2.5^{\circ} \%$ \\
\hline $\begin{array}{r}105 \\
45 \\
65\end{array}$ & $\begin{array}{l}\text { No anti-D serum } \\
\text { Anti-D serum added } \\
\text { No anti-D serum } \\
\text { Anti-D serum added } \\
\text { No anti-D serum } \\
\text { Anti-D serum added } \\
\text { No anti-D serum } \\
\text { Anti-D serum added } \\
\text { No anti-D serum } \\
\text { Anti-D serum added } \\
\text { No anti-D serum } \\
\text { Anti-D serum added } \\
\text { No anti-D serum } \\
\text { Anti-D serum added }\end{array}$ & $\begin{array}{l}++ \\
++ \\
+ \\
++ \\
+++ \\
+++ \\
++ \\
++ \\
++ \\
++ \\
+++ \\
++ \\
+++\end{array}$ & $\begin{array}{l}++ \\
++ \\
++ \\
+ \\
++++ \\
++ \\
++ \\
++++ \\
++ \\
++ \\
+++ \\
+++ \\
++++\end{array}$ & $\begin{array}{l}+++ \\
+++ \\
++ \\
+++ \\
++++ \\
++ \\
++ \\
++++ \\
++ \\
+++ \\
++++ \\
++++ \\
++++\end{array}$ & $\begin{array}{l}+++ \\
+++ \\
++ \\
+++ \\
++++ \\
+++ \\
+++ \\
+++ \\
++ \\
+++ \\
++ \\
+++ \\
++ \\
++++\end{array}$ & $\begin{array}{l}++ \\
+++ \\
+ \\
+++ \\
++ \\
+++ \\
++ \\
+++ \\
++ \\
++ \\
++ \\
+++ \\
+++\end{array}$ & $\begin{array}{l}- \\
\pm \\
+ \\
+ \\
++ \\
++ \\
+++ \\
+++ \\
++ \\
+ \\
+++ \\
+ \\
+++\end{array}$ \\
\hline
\end{tabular}

$++++=$ clear spaces more than $1 \mathrm{~mm}$. wide between the red cell clumps $;+++=$ clear spaces less than $1 \mathrm{~mm}$. wide between the red cell clumps $;++=$ the red cells form a continuous column, but clumping evident $;+=$ a definite irregularity of the red cell column $\pm=$ a barely perceptible irregularity of the red cell column ; $-=$ the red cell column shows no irregularity. 


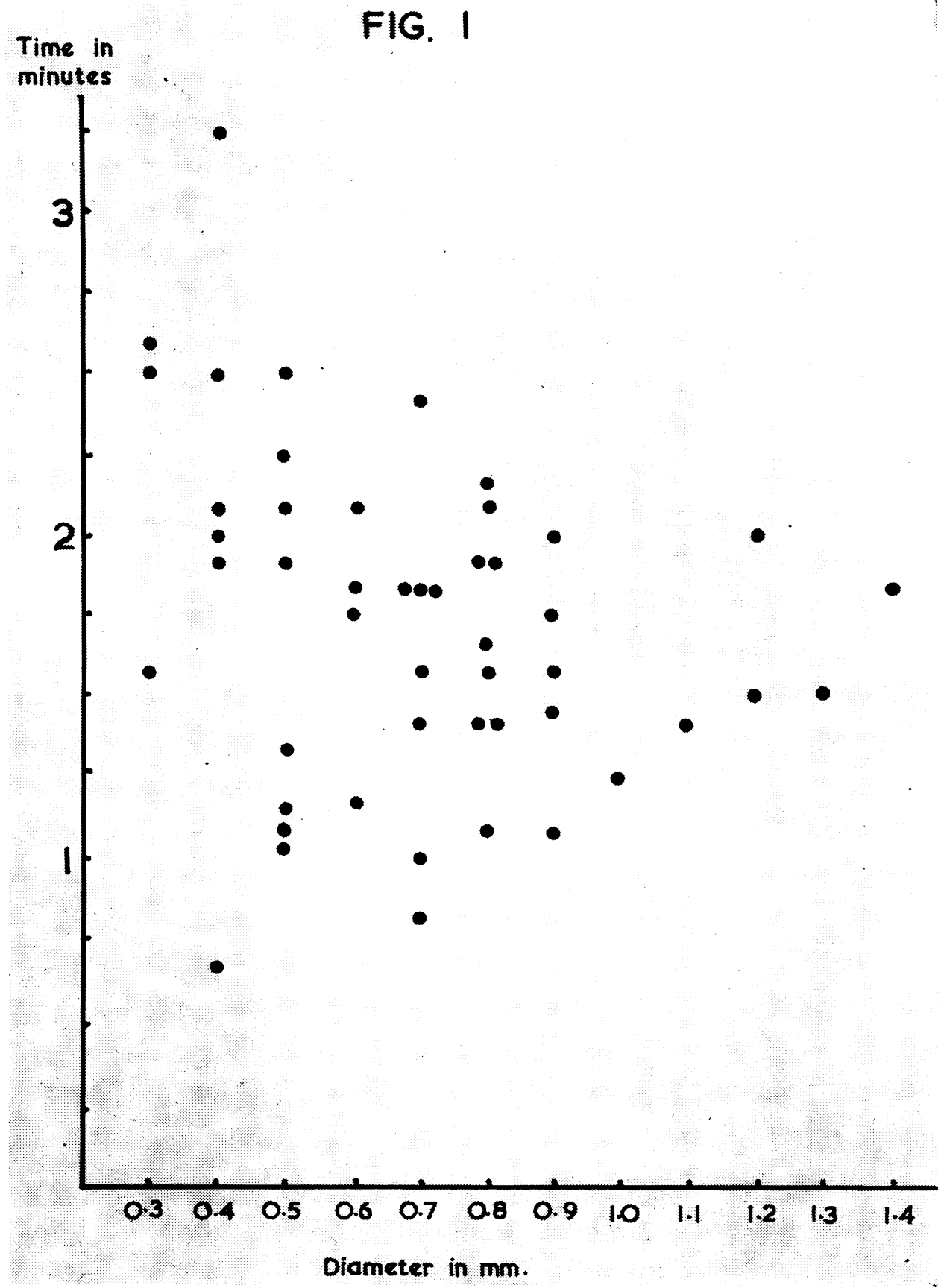


Rhesus-positive patients at varying dilutions of cells in their own sera. The blood specimens were first centrifuged and appropriate dilutions of packed cells in serum were prepared.

These results make it clear that the Chown test, using a suspension of red cells in their own serum, is not trustworthy in patients with a high E.S.R. In order to test the effect of different diluting fluids, we made 192 observations with cell suspensions from three of these blood samples. Eight different concentrations of cells were used, ranging from $40 \%$ to $0.5 \%$. They were diluted with (1) their own serum ; (2) serum from a healthy subject of group AB ; (3) citrate saline ; and (4) citrate saline using cells which had been washed three times. It was found that by using citrate saline suspensions false positive results due to rouleau formation could be avoided. There seems to be no advantage in washing the cells previously. With AB serum, however, false positive results can still be obtained, though they are generally weaker than those which appear when suspensions of cells in their own serum are employed. Citrate saline suspensions give much less clearly marked positive results than those obtained with serum suspensions, and in high dilution false negative results may be obtained.

Effect of Dilution in Producing False Negatives.-The speed at which a positive result is obtained depends to a varying extent on the concentration of the cell suspension used. Table III shows the times taken in minutes for a positive result to appear when ten blood samples were diluted to a varying degree with their own serum.

TABLE III

Timing (Minutes) of Positive Result in Varying Dilutions of Ten Blood Samples

\begin{tabular}{c|c|c|c|c|c|c|c|c}
\hline \multirow{2}{*}{$\begin{array}{c}\text { Blood } \\
\text { Sample }\end{array}$} & \multicolumn{8}{c}{ Dilution } \\
\cline { 2 - 19 } & $1: 1$ & $1: 2$ & $1: 4$ & $1: 8$ & $1: 16$ & $1: 32$ & $1: 64$ & $1: 128$ \\
\hline 1 & 3 & 5 & 5 & 7 & 7 & 10 & 9 & 6 \\
2 & 4 & 3 & 4 & 5 & 7 & 6 & 7 & 7 \\
3 & 3 & 3 & 4 & 4 & 4 & 5 & 4 & 5 \\
4 & 3 & 3 & 4 & 4 & 6 & 6 & 6 & 6 \\
5 & 2 & 2 & 4 & 3 & 3 & 2 & 2 & 2 \\
6 & 4 & 3 & 3 & 2 & 3 & 4 & 4 & 4 \\
7 & 5 & 7 & 10 & 7 & 10 & 9 & 8 & 9 \\
8 & 4 & 3 & 3 & 6 & 7 & 7 & 7 & 10 \\
9 & 2 & 10 & 11 & 12 & 13 & 11 & 10 & 9 \\
10 & 7 & 14 & 14 & 14 & 14 & 14 & 14 & 13 \\
\hline
\end{tabular}

The delaying effect of dilution is much more marked with citrate saline suspensions. Table IV shows the time in minutes taken for the test to become positive when varying dilutions in citrate saline are employed.

Effect of Age of the Blood Sample Tested.-Discombe and Meyer (1948) drew attention to the fact that blood samples which are not fresh may give false negative results. In Fig. 2 the times taken to reach a positive result are shown for 55 blood samples, known to be Rhesus-positive, which had been collected up to 10 days previously. A positive result was eventually obtained in every case. It will be seen that for blood samples up to five days old no great difference is apparent. After that, 
TABLE IV

Timing (Minutes) of Positive Result in Dilutions with Citrate Saline in Seven Blood Samples

\begin{tabular}{|c|c|c|c|c|c|c|c|c|c|}
\hline \multirow{2}{*}{$\begin{array}{c}\text { Blood } \\
\text { Sample }\end{array}$} & \multicolumn{9}{|c|}{ Dilution } \\
\hline & $1: 1$ & $1: 2$ & $1: 4$ & $1: 8$ & $1: 16$ & $1: 32$ & $1: 64$ & $1: 128$ & $1: 256$ \\
\hline 1 & 2 & 7 & 8 & 15 & 27 & 24 & 35 & 38 & 61 \\
\hline 2 & 7 & 9 & 10 & 11 & 18 & 18 & 23 & 25 & 27 \\
\hline 3 & 5 & 10 & 11 & 14 & 17 & 29 & 29 & 35 & 38 \\
\hline 4 & 4 & 9 & 11 & 15 & 15 & 17 & 17 & 29 & 31 \\
\hline 5 & 3 & 6 & 10 & 12 & 17 & 26 & 26 & 34 & 81 \\
\hline 6 & 3 & 7 & 11 & 13 & 14 & 14 & 21 & 22 & 28 \\
\hline 7 & 3 & 7 & 8 & 13 & 17 & 31 & 40 & 43 & 43 \\
\hline
\end{tabular}

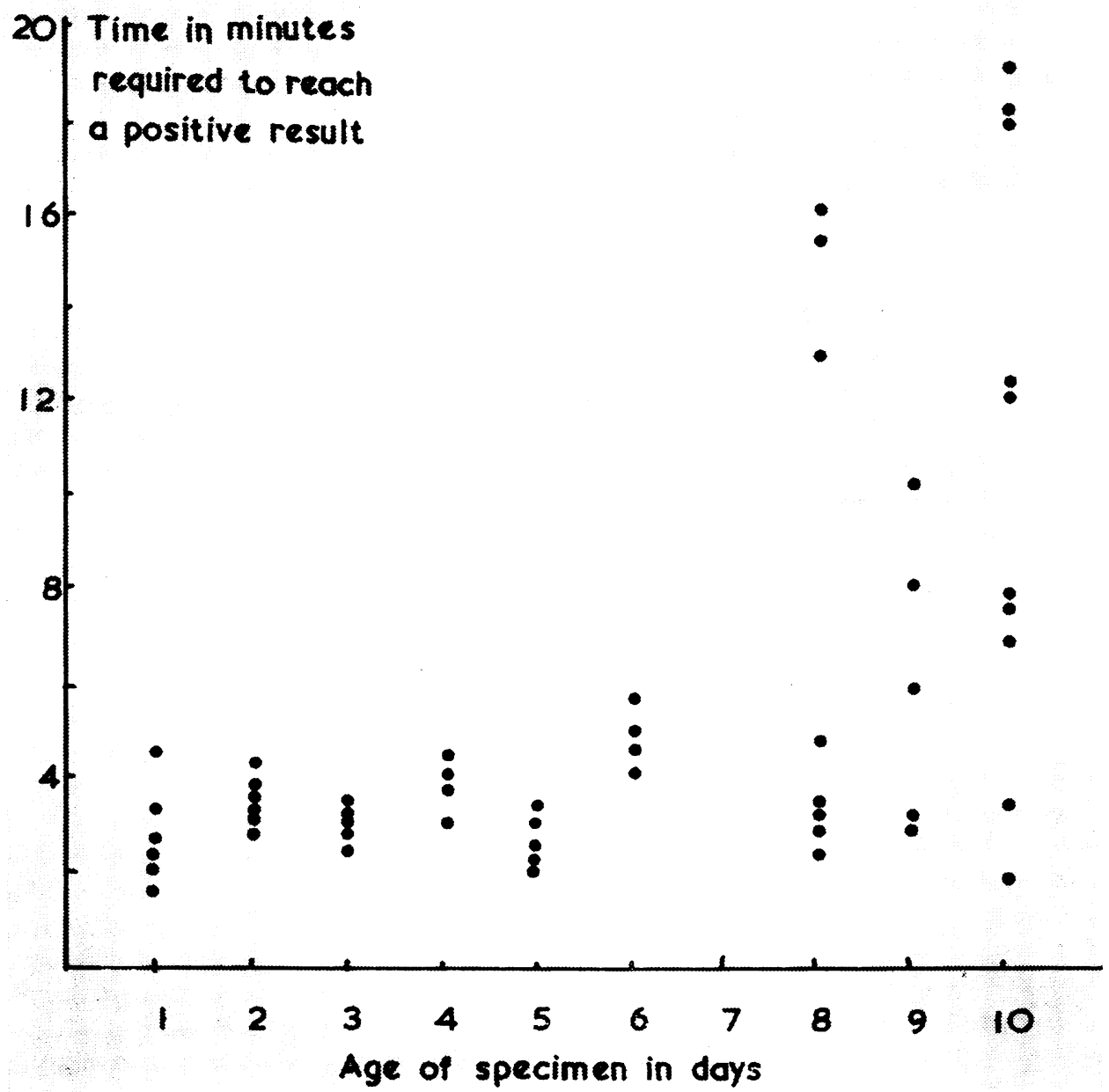


however, some show considerable delay in the development of a positive reaction, although others give results after times comparable with those of the fresher specimens.

\section{Conditions for Satisfactory Results by the Tube Centrifuging Method}

As has been shown, reliable results can be achieved by this method if the tubes are incubated for 10 minutes and then centrifuged for five minutes. These times cannot be shortened to any great extent without sacrificing the reliability of the test. There is, of course, no objection to prolonging either time.

It was feared at first that prolonged centrifuging might, in a negative reaction, pack the cells so tightly together that false positive results could occur. Accordingly five tests were set up with known Rhesus-negative blood samples and centrifuged for 30 minutes. All were clearly negative at the end of this time. In five more tests, with 60 minutes' centrifuging, all results were again obviously negative.

In order to test the validity of the tube centrifuging method with anti-D sera of varying titre, ten blood samples, seven Rhesus positive and three Rhesus negative, were tested with each of five different antisera of titre varying from $1: 2$ to $1: 32$. Five different observers, who had no previous experience of the test, were asked to read the results. A sixth observer determined the Rhesus groups by the standard tube method. No discrepancies were found.

\section{Discussion}

The extent of error which we have found in the routine use of the Chown test (20 discrepancies in 917 consecutive observations) is approximately the same as that encountered by Discombe and Meyer (1948). These authors examined 403 blood specimens ; three were rejected as unsatisfactory specimens, although two of the three gave adequate results with the tube method. A further eight results are described as doubtful. Thus, in 10 out of $\mathbf{4 0 2}$ cases which gave satisfactory results by the tube method, they found the Chown test inadequate. Discombe and Meyer's technique differs from ours in that they used saline suspensions of cells and incubated their capillary tubes at $37^{\circ} \mathrm{C}$.

The most serious source of error in the Chown test seems to be the occurrence of false positive results due to rouleau formation when serum suspensions of cells are used. False negative results are, on the other hand, apparently caused by a variety of factors which delay the appearance of a positive result beyond the time selected for reading the test. One of these factors is dilution, which delays the appearance of a positive reaction both with serum and with saline suspensions, but to a much greater extent with saline suspensions. Another delaying factor is the age of the specimen of blood : with specimens over five days old considerable delay may occur, but up to this time little difference can be detected.

False positive results due to rouleau formation can be avoided by the use of saline suspensions, but if this modification is adopted there will be an increased risk of false negative results if some of the cell suspensions are unduly weak. To centrifuge the cells and then dilute them accurately is undesirably tedious in a routine laboratory procedure. Great prolongation of the time of the test is dangerous, as in rapidly reacting specimens the cells quickly fall to the bottom of the tube and the test becomes difficult to read. All sources of error could probably be avoided by using a $20 \%$ 
suspension of cells in citrate saline and observing the test every few minutes for half an hour. If this is to be done, the Chown test is by no means a simple and rapid technique, and its principal advantages disappear.

The Diamond slide test is a rapid method of which we have no personal experience. Its authors state that rouleau formation is a frequent complication. We believe that any test which depends for its success on the certain differentiation of agglutination from rouleau formation is liable to give rise to error except in the most experienced hands. Such a method is unsuitable for a routine laboratory.

In contrast, the tube centrifuging method which has been described gave no discrepancies in 540 observations. It is easy to perform and can be read by inexperienced observers without difficulty. In addition it makes possible the use of antisera which would normally be considered too weak for grouping purposes.

\section{Summary}

In 917 consecutive routine determinations of Rhesus groups by the Chown capillary tube method, 20 erroneous results were obtained, nine being false positive and 11 false negative reactions.

These observations were carried out in parallel with the standard tube method, which gave no false results in this series.

False positive Chown tests appear to be due to rouleau formation when suspensions of cells in serum are used : this can be avoided by using saline suspensions.

False negative results can be obtained by the Chown test if insufficient time is allowed for the development of a positive result : factors delaying its appearance are dilution, the use of saline as opposed to serum suspensions, and the use of blood specimens more than five days old.

A method is described for rapid Rhesus group determination in a tube which is incubated for 10 minutes at $37^{\circ} \mathrm{C}$. and then centrifuged for five minutes at 2,000 to 2,500 r.p.m. This method gave no discrepancies in 540 observations carried out in parallel with the standard tube method.

Our thanks are due to $\mathrm{D}_{i}$. A. H. T. Robb-Sm.th, Director of Pathology, Radcliffe Infirmary, Oxford, and Dr. R. G. Macfarlane, in whose department these investigations were carried out; to Dr. R. G. Macfarlane and Dr. M. M. Pickles for constant advice and encouragement; and to Mr. J. A. Morton and Miss J. Cruse, who carried out many of the routine observations which we have reported.

\section{REFERENCES}

Boorman, K. E., Dodd, B. E., and Mollison, P. L. (1942). Brit. med. J., 2, 535.

Chown, B. (1944). Amer. J. clin. Path, 14, Tech. Sect., 8, 114.

- and Lewis, M. (1946). Canad. med. Ass. J., 55, 66.

Diamond, L. K., and Abelson, N. M. (1945). J. Lab. clin. Med., 30, 204.

Discombe, G., and Meyer, H. (1948). J. clin. Path, 1, 73.

Landsteiner, K., and Wiener, A. S. (1941). J. exp. Med., 74, 309.

Mollison, P. L., Mourant, A. E., and Race, R. R. (1948). Med. Res. Coun. Spec. Memo. No. 19, p. 59.

Taylor, G. L. (1943). Proc. R. Soc. Med., 36, 225. 